Vol 5. No 2. Agustus 2021

ISSN 2580-5029

\title{
Uji Cemaran Mikroba Pada Air Yang Digunakan Untuk Mencuci Peralatan Makan Oleh Pedagang Kaki Lima di Sekitar UIN Sunan Ampel Surabaya
}

\author{
Fahimatul Ula ${ }^{*}$, Misbakhul Munir ${ }^{2}$, Hanik Faizah ${ }^{3}$ \\ 1 Program Studi Biologi, Fakultas Sains dan Teknologi UIN Sunan Ampel Surabaya, Indonesia \\ 2 Program Studi Biologi, Fakultas Sains dan Teknologi UIN Sunan Ampel Surabaya, Indonesia \\ ${ }^{3}$ Program Studi Biologi, Fakultas Sains dan Teknologi UIN Sunan Ampel Surabaya, Indonesia \\ * fahimatulula16@gmail.com
}

\section{ABSTRACT}

The condition of eating places such as street vendors will determine the level of food hygiene, including the water used to wash food utensils. This study aimed to determine the number of microbes and identify Escherichia coli and Salmonella sp. on the water that was used to wash tableware by street vendors around UIN Sunan Ampel Surabaya. Water samples before and after being used to wash tableware were obtained from 4 street vendors. The number of microbes in the sample was tested by the Total Plate Count (TPC) and Most Probable Number (MPN) methods, Escherichia coli was identified using Eosin Methylene Blue Agar (EMB) media, and Salmonella sp. was identified using Salmonella-Shigella agar (SSA) and Triple Sugar Iron agar (TSIA) media. Based on the results of TPC test, the water sample before being used to wash tableware had the lowest and highest values that were $3.0 \times 10^{2} \mathrm{Cfu} / \mathrm{ml}$ and $9.8 \times 10^{5} \mathrm{Cfu} / \mathrm{ml}$, respectively, while the water sample after being used to wash tableware had the lowest and highest values that were 4.0 $\mathrm{x} 10^{2} \mathrm{Cfu} / \mathrm{ml}$ and $3.5 \times 10^{5} \mathrm{Cfu} / \mathrm{ml}$, respectively. In the MPN test, the water sample before being used to wash tableware had the lowest and highest values that were $15 / 100 \mathrm{ml}$ and $26100 / \mathrm{ml}$, respectively, while the water sample after being used to wash tableware had the lowest and highest values that were $72 / 100 \mathrm{ml}$ and $271 / 100 \mathrm{ml}$, respectively. Escherichia coli was detected in all samples $1 \& 3$ while in sample 2 Escherichia coli was detected in the water before it was detected the genus Enterobacter and in samples 4 the genus Enterobacter was detected and all samples water used to wash tableware of street vendors was positive for Salmonella.

Keywords: Street Vendors, coliform bacteria, TPC (Total Plate Count), MPN (Most Probable Number), tableware washing water

\section{ABSTRAK}

Kondisi tempat makan seperti warung makan di pinggir jalan (PKL) akan menentukan tingkat higienisitas suatu makanan, diantaranya yaitu air yang digunakan untuk mencuci peralatan makanan. Penelitian ini bertujuan untuk mengetahui jumlah mikroba serta mengidentifikasi Escherichia coli dan Salmonella sp. pada air yang digunakan mencuci peralatan makan pedagang kaki lima (PKL) di sekitar UIN Sunan Ampel Surabaya. Sampel air sebelum dan sesudah digunakan untuk mencuci peralatan makan diperoleh dari 4 pedagang kaki lima. Jumlah mikroba pada sampel diuji dengan Metode Total Plate Count (TPC) dan Most Pobable Number (MPN). Escherichia 
coli diidentifikasi menggunakan media Eosin Methilen Blue Agar (EMB), dan Salmonella sp. di identifikasi menggunakan media Salmonella Shigella Agar (SSA) dan Triple Sugar Iron Agar (TSIA). Berdasarkan hasil penelitian pada uji TPC, sampel air sebelum mencuci peralatan makan memiliki nilai terendah yaitu $3,0 \times 10^{2} \mathrm{Cfu} / \mathrm{ml}$ dan tertinggi, yaitu $9,8 \times 10^{5} \mathrm{Cfu} / \mathrm{ml}$, sedangkan pada sampel air sesudah digunakan mencuci peralatan makan memiliki nilai terendah, yaitu $4,0 \times 10^{2} \mathrm{Cfu} / \mathrm{ml}$ dan tertinggi yaitu 3,5 x $10^{5} \mathrm{Cfu} / \mathrm{ml}$. Pada uji MPN, sampel air sebelum digunakan mencuci peralatan makan memiliki nilai terendah, yaitu 15/100ml dan tertinggi, yaitu $26100 / \mathrm{ml}$, dan pada sampel air sesudah digunakan mencuci peralatan makan nilai terendah, yaitu $72 / 100 \mathrm{ml}$ dan tertinggi, yaitu 271/100 ml. Escherichia coli terdeteksi pada semua sampel $1 \& 3$, sedangkan pada sampel 2 Escherichia coli terdeteksi pada air sesudah sedangkan pada air sebelum terdeteksi genus Enterobacter dan pada semua sampel 4 terdeteksi genus Enterobacter dan semua sampel air yang digunakan mencuci peralatan makan PKL dinyatakan positif Salmonella.

Kata kunci: PKL (Pedagang Kaki Lima), bakteri coliform, TPC (Total Plate Count), MPN (Most Probable Number), air cucian peralatan makan.

\section{PENDAHULUAN}

Pedagang kaki lima atau disingkat (PKL) merupakan pedagang yang melakukan aktifitas perdagangan baik makanan maupun minuman yang berada dipinggir jalan maupun tempat umum dengan menggunakan gerobak atau tempat yang mudah dibongkar pasang. Selain itu, pedagang kaki lima memiliki dagangan dengan harga yang lebih murah dibandingkan dengan harga makanan di warung (Paulus, 2007).

Universitas Islam Negeri Sunan Ampel Surabaya merupakan salah satu perguruan tinggi negeri yang berada di Kota Surabaya. Kawasan di sekitar Universitas ramai oleh penjual makanan maupun minuman kaki lima seperti bakso, mie ayam, siomay, dan lain-lain.

Makanan dan minuman yang dijual pedagang kaki lima memiliki resiko tinggi terkontaminasi bakteri karena dijual di tempat terbuka, sehingga mudah terkontaminasi oleh polusi udara dan terdapat banyak lalat. Selain itu, kontaminasi pada makanan bisa juga disebabkan karena air yang digunakan untuk mencuci peralatan makan tidak bersih atau sudah kontaminasi mikroba hal ini bisa terjadi karena air digunakan mencuci secara berulang-ulang dan spon yang digunakan untuk mencuci peralatan makan tidak dicuci dengan bersih setelah digunakan (Nicholas, 2006). Oleh karena itu, air yang digunakan untuk mencuci peralatan makan harus memenuhi standar syarat air bersih. Menurut Peraturan Menteri Kesehatan Republik Indonesia No. 416/MENKES/PERIX/1990 yaitu syarat dari kualitas air bersih dengan total coliform (MPN) pada air perpipaan sebesar 10/100 ml sampel dan untuk air yang bukan perpipaan yaitu 50/100 ml (Depkes RI, 2011).

Beberapa penelitian menunjukkan bahwa terdapat cemaran bakteri coliform pada sampel air pencucian peralatan makan. Berdasarkan penelitian Prasumma (2013) pada bakteri coliform dalam air cucian alat 
makan pada warung-warung dipabelan sukoharjo, hasil dari 2 sampel air cucian alat makan sebelum dan sesudah digunakan didapatkan total bakteri coliform yaitu $>50 / 100 \mathrm{ml}$ sampel air non perpipaan hal ini menunjukkan bahwa sampel air tidak memenuhi syarat air bersih, dan berdasarkan penelitian Budon (2013) didapati hasil bahwa dari 4 kantin, 3 kantin tidak memenuhi syarat kualitas bakteriologis air pencucian dan peralatan makan dikantin Uin Alaudin, bahwa sampel air melebihi ambang batas coliform yaitu $>2400$, hal ini menunjukkan bahwa air dikantin tidak memenuhi syarat sebagai air bersih.

Bakteri coliform adalah bakteri yang berada dikotoran manusia maupun hewan, bakteri ini dapat dijadikan indikator untuk uji kualitas makan dan air bersih, bakteri coliform merupakan flora normal dan hidup disaluran pencernaan. Bakteri coliform sendiri dibagi menjadi dua yaitu coliform fekal contohnya Escerichia coli, Enterobacter aerogenes dan coliform non fekal contohnya Aerobacter, Citrobacters sp. dan Serrati sp. Adanya bakteri coliform Escherichia coli dapat menyebabkan gejala gangguan pada foodborne disease yaitu sakit perut, diare, muntah, demam, mual, dan lain-lain. Sedangkan pada Salmonella sp. dapat menyebabkan demam tifoid, gastroenteritis, dan lain-lain (Agus, 2009).

Berdasarkan uraian diatas tentang pentingnya menjaga kebersihan makanan dan air yang digunakan untuk membersihkan peralatan makanan agar tidak terkontaminasi oleh bakteri coliform, maka penelitian ini dilakukan untuk mengetahui cemaran mikroba dengan menghitung total mikroba dan total coliform serta mendeteksi adanya Escherichia coli dan Salmonella sp. pada sampel air yang digunakan untuk mencuci peralatan makan pedagang kaki lima di sekitar Universitas Islam Negeri Sunan Ampel Surabaya.

\section{METODE}

\section{Sampel Penelitian}

Penelitian ini dilakukan pada bulan Juli-Desember 2020 di laboratorium terintegrasi Universitas Islam Negeri Sunan Ampel Surabaya. Jenis penelitian ini merupakan penelitian deskriptif. Sampel yang digunakan dalam penelitian ini yaitu 8 sampel dari 4 pedagang kaki lima yaitu pada setiap pedagang diambil 2 sampel air. Sampel berupa air sebelum digunakan mencuci dan sampel air sesudah digunakan mencuci peralatan makan pedagang kaki lima di sekitar Universitas Islam Negeri Sunan Ampel Surabaya. Sampel dimasukkan kedalam botol steril dan diuji untuk mengetahui total mikroba, nilai MPN dan mengidentifikasi Escherichia coli serta Salmonella sp. 


\section{Pengujian Total Mikroba Dengan Metode TPC}

Pengujian menggunakan metode TPC dilakukan dengan cara mengambil $1 \mathrm{ml}$ sampel air, kemudian ditambahkan $9 \mathrm{ml}$ pengencer (akuades) dan akan didapatkan pengenceran $10^{-1}$ dan dari pengenceran $10^{-1}$ akan diambil $1 \mathrm{ml}$ dan dimasukkan kedalam $9 \mathrm{ml}$ akuades steril untuk didapatkan hasil pengenceran $10^{-2}$ dan dari pengenceran $10^{-2}$ akan diambil $1 \mathrm{ml}$ dan dimasukkan kedalam $9 \mathrm{ml}$ akuades untuk menghasilkan pengenceran 10-3. Masing-masing hasil pengenceran sampel, diambil $1 \mathrm{ml}$ untuk dimasukkan diatas cawan petri yang berisi media NA (Nutrient Agar) 20 ml. Setelah itu, cawan petri diputar membentuk angka delapan, cawan petri dibalik apabila sudah mengeras dan diinkubasi pada suhu $37^{\circ} \mathrm{C}$ selama 24-48 jam, kemudian dihitung jumlah koloni yang tumbuh dipermukaan cawan dengan menggunakan coloni counter (Kusumaningsih, 2013).

\section{Pengujian Bakteri Coliform Dengan Metode MPN}

Uji MPN pada penelitian ini dilakukan menggunakan ragam 333 dan memiliki 3 tahapan yaitu uji praduga, uji penegasan dan uji pelengkap. Uji praduga (Persumtive Test) dilakukan dengan cara mengambil sampel sebanyak $1 \mathrm{ml}$ dan 0,1 $\mathrm{ml}$ untuk dimasukkan kedalam 6 tabung LBSS (lactose broth single strength) yang sudah berisi tabung durham dan $10 \mathrm{ml}$ untuk dimasukkan kedalam 3
LBDS (laktosa broth double strength) yang sudah berisi tabung durham, kemudian diinkubasi pada suhu $37^{\circ} \mathrm{C}$ selama 24-48 jam. Pada Uji Penegasan (Confirmative Test), biakan positif dari setiap tabung LB (Lactose Broth) diinokulasikan sebanyak 1-2 ose kedalam tabung yang berisi $9 \mathrm{ml}$ media BGLB (Brilliant Green Lactose Broth) yang berisi tabung durham. Lalu tabung BGLB diinkubasi pada suhu $35^{\circ} \mathrm{C}$ selama $24-48$ jam. Pada Uji Pelengkap (Completed Test), Masing-masing biakan positif pada uji penegasan diambil satu ose dan diinokulasikan pada media EMBA (Eosin Metilen Blue Agar), kemudian diinkubasi pada suhu $35^{\circ} \mathrm{C}$ selama 24 jam. Adanya bakteri Escherichia coli ditandai dengan terbentuknya koloni berwarna hijau metalik (Nugroho, 2006).

\section{Pengujian Bakteri Salmonella Sp.}

Pengujian bakteri salmonella $s p$. dilakukan dengan menggunakan media SSA (Salmonella shigella agar) dan TSIA (Triple Sugar Iron Agar). Sampel sebanyak $1 \mathrm{ml}$ diinokulasikan dengan menggunakan jarum ose pada media SSA dan diinkubasi dengan suhu $35^{\circ} \mathrm{C}$ selama 24 jam. Koloni bakteri Salmonella sp. yang terbentuk ditandai dengan adanya warna bening dengan bintik hitam pada koloni. Koloni yang diduga bakteri Salmonella sp. diinokulasikan pada media TSIA (Triple Sugar Iron Agar) dengan menggunakan jarum ose ditusukkan kedasar agar lalu digoreskan dengan posisi miring, dan diinkubasi $35^{\circ} \mathrm{C}$ selama 24 jam. Hasil 
positif koloni akan terlihat pada dasar agar berwarna kuning menunjukkan hasil asam ,dan hasil negatif pada agar miring berwarna merah menunjukkan hasil bersifat basa, kemudian terdapat $\mathrm{H}_{2} \mathrm{~S}$ berwarna hitam serta dilihat dengan adanya gas maupun tidak (Cappucino \& Sherman, 1987).

\section{HASIL DAN PEMBAHASAN}

\section{Jumlah Perhitungan Mikroba Metode TPC}

Berdasarkan perhitungan jumlah mikroba dengan menggunakan metode TPC, sampel air sebelum digunakan mencuci peralatan makan oleh PKL memiliki jumlah koloni terendah, yaitu $3,0 \times 10^{2} \mathrm{Cfu} / \mathrm{ml}$, dan jumlah koloni tertinggi, yaitu 9,8 x $10^{2}$ $\mathrm{Cfu} / \mathrm{ml}$, sedangkan pada sampel air sesudah digunakan mencuci peralatan makan oleh PKL memiliki jumlah koloni yang meningkat dari sampel air sebelum digunakan mencuci peralatan makan, dengan jumlah koloni terendah, yaitu 4,0 x $10^{2} \mathrm{Cfu} / \mathrm{ml}$, dan jumlah koloni tertinggi, yaitu 3,5 x $10^{5} \mathrm{Cfu} / \mathrm{ml}$ (Tabel 1).

Tabel 1. Data Hasil Metode TPC

\begin{tabular}{llc}
\hline \multicolumn{2}{c}{$\begin{array}{c}\text { Sampel Air yang } \\
\text { digunakan mencuci } \\
\text { peralatan Makan PKL }\end{array}$} & $\begin{array}{c}\text { Jumlah Cemaran } \\
\text { Mikroba Cfu/ml }\end{array}$ \\
\hline \multirow{2}{*}{1} & Sebelum & $9,5 \times 10^{2}$ \\
\cline { 2 - 3 } & Sesudah & $2,5 \times 10^{3}$ \\
\hline \multirow{2}{*}{2} & Sebelum & $9,8 \times 10^{2}$ \\
\cline { 2 - 3 } & Sesudah & $3,5 \times 10^{5}$ \\
\hline \multirow{2}{*}{3} & Sebelum & $8,7 \times 10^{2}$ \\
\cline { 2 - 3 } & Sesudah & $2,9 \times 10^{3}$ \\
\hline \multirow{2}{*}{4} & Sebelum & $3,0 \times 10^{2}$ \\
\cline { 2 - 3 } & Sesudah & $4,0 \times 10^{2}$ \\
\hline
\end{tabular}

Sumber:Dokumentasi Pribadi 2020

Dari hasil observasi, air yang digunakan mencuci peralatan makan oleh PKL memiliki kandungan mikroba yang cukup tinggi pada sampel ke-1 dengan jumlah koloni yaitu 9,5 x $10^{2} \mathrm{Cfu} / \mathrm{ml}$. Kontaminasi ini diduga berasal dari air yang digunakan PKL yang bersumber dari air sumur bor yang letaknya berada ditempat terbuka, dan dekat dengan tempat sampah, sehingga kemungkinan terjadinya kontaminasi mikroba semakin tinggi. sedangkan pada sampel ke-3 memiliki jumlah koloni yang lebih rendah dari sampel ke-1, yaitu $8,7 \times 10^{2} \mathrm{Cfu} / \mathrm{ml}$. Sampel air ini bersumber dari sumur bor dekat rumah warga dengan kondisi sumur yang tertutup. Menurut Pelczar dan Chan (2008) air sumur merupakan air yang berada dibawah permukaan tanah dan memiliki pori-pori sehingga mikroorganisme tertahan oleh bahan partikulat dalam tanah sebagai penyaring, sehingga kemungkinan air didalam tanah bebas dari mikroorganisme. Hal ini berbeda dengan pernyataan Suryanti (2019) bahwa air sumur memiliki resiko tercemar mikroba karena air bersumber dari tanah yang dangkal sehingga menyebabkan air tercemar.

Sampel air ke-2 memiliki jumlah cemaran tertinggi dengan jumlah koloni, yaitu 9,8 x $10^{2} \mathrm{Cfu} / \mathrm{ml}$. Kontaminasi ini berasal dari sumber air PDAM yang memiliki warna keruh, dan air tersebut diletakkan di dalam ember dalam kondisi terbuka. Sedangkan pada sampel ke-4 memiliki 
jumlah koloni terendah dari semua sampel, yaitu $3,0 \times 10^{2} \mathrm{Cfu} / \mathrm{ml}$. Sumber air yang digunakan pada sampel ke-4 berasal dari air PDAM dan air tersebut diletakkan pada ember dengan kondisi tertutup. Menurut Haryamani dan Konsukartha (2007) bahwa air sumur mudah terkontaminasi oleh bakteri dari sisa pembuangan manusia karena sumur tidak kedap air, dan kondisi sumur yang terbuka membuat air mudah terkontaminasi bakteri yang ada disekitar sumur.

Pada sampel ke-1 air sesudah digunakan mencuci peralatan makan PKL di sekitar UIN Sunan Ampel Surabaya memiliki jumlah koloni yang meningkat dari 9,5 x $10^{2}$ $\mathrm{Cfu} / \mathrm{ml}$ menjadi $2,5 \times 10^{3} \mathrm{Cfu} / \mathrm{ml}$. Hal ini dapat disebabkan karena lingkungan tempat berjualan yang kumuh, selain itu pedagang hanya menggunakan 1 ember yang digunakan mencuci peralatan makan dan meletakkannya di dekat tempat sampah sehingga mengundang datangnya lalat, sedangkan pada sampel ke-2 air sesudah digunakan mencuci peralatan makan PKL mengalami peningkatan tertinggi dari 9,8 $\mathrm{x}$ $10^{2} \mathrm{Cfu} / \mathrm{ml}$ menjadi $3,5 \mathrm{x} 10^{5} \mathrm{Cfu} / \mathrm{ml}$. Kontaminasi ini berasal dari air yang digunakan hanya 1 ember untuk mencuci peralatan makan dan digunakan secara berulang-ulang dengan kondisi air yang tidak mengalir, dan penjual juga tidak mengganti air yang sudah keruh. Hal ini sesuai dengan pernyataan Melawati (2010) bahwa air yang digunakan mencuci peralatan makan secara berulang-ulang membuat air menjadi kotor dan terkontaminasi oleh bakteri.

Pada sampel ke-3 air sesudah digunakan juga mengalami peningkatan dari $8,7 \times 10^{2} \mathrm{Cfu} / \mathrm{ml}$ menjadi $2,9 \times 10^{3} \mathrm{Cfu} / \mathrm{ml}$, karena hanya menggunakan 1 ember dengan kondisi air yang tidak mengalir dan digunakan berulang-ulang, pada sampel ke-4 air sesudah digunakan mencuci peralatan makan PKL mengalami peningkatan jumlah koloni dari 3,0 x $10^{2} \mathrm{Cfu} / \mathrm{ml}$ menjadi 4,0 x $10^{2}$ $\mathrm{Cfu} / \mathrm{ml}$, hal ini karena PKL menggunakan 2 ember air, yaitu 1 ember untuk mencuci dan 1 ember untuk pembilasan dengan kondisi air yang tertutup dan menggantinya jika sudah digunakan berulang-ulang. Peningkatan jumlah koloni ini tidak terlalu banyak dibandingkan dengan yang hanya menggunakan 1 ember saja, namun masih lebih baik jika mencuci peralatan makan menggunakan 3 bak pencucian.

Hal ini sejalan dengan penelitian Budiati (2015) dari hasil penelian higiene dan sanitasi di warung $\mathrm{x}$ Kabupaten Kudus dengan jumlah koloni bakteri terbanyak yaitu 9 x $10^{5} \mathrm{Cfu} / 100 \mathrm{ml}$ dan terendah $3,2 \mathrm{x}$ $10^{5} \mathrm{Cfu} / 100 \mathrm{ml}$ sehinga terjadi kualitas penurunan air yang dapat meningkatkan faktor water borne diseases hal ini karena pencucian piring hanya menggunakan 2 bak pencucian dan dianggap kurang baik karena seharusnya menggunakan 3 bak yaitu untuk mengguyur, menyabun, dan membilas. 


\section{Jumlah Coliform Berdasarkan Nilai MPN}

\section{Uji Praduga}

Berdasarkan hasil penelitian pada uji praduga, hasil positif ditandai dengan adanya kekeruhan dan terbentuknya asam serta gelembung gas dalam tabung durham pada media LB (Gambar 1). Hal ini terjadi karena tabung reaksi yang tertutup rapat menyebabkan gas karbon pada tabung durham terdorong dan dalam waktu 24 jam maka akan banyak ruang gas yang terbentuk dan menyebabkan perubahan warna akibat fermentasi laktosa (Putri, 2018).

Tabel 2. Data Hasil Uji Praduga

\begin{tabular}{|c|c|c|c|c|}
\hline & \multirow[b]{2}{*}{ Sampel } & \multicolumn{3}{|c|}{ Hasil Uji Praduga } \\
\hline & & $\begin{array}{c}3 \times 10 \\
\mathrm{ml}\end{array}$ & $\begin{array}{c}3 \times 1 \\
\mathrm{ml}\end{array}$ & $\begin{array}{c}3 \times 0,1 \\
\mathrm{ml}\end{array}$ \\
\hline \multirow{2}{*}{1} & Sebelum & 2 & 2 & 1 \\
\hline & Sesudah & 3 & 2 & 1 \\
\hline \multirow{2}{*}{2} & Sebelum & 2 & 1 & 1 \\
\hline & Sesudah & 3 & 1 & 2 \\
\hline \multirow{2}{*}{3} & Sebelum & 2 & 2 & 1 \\
\hline & Sesudah & 3 & 3 & 0 \\
\hline \multirow{2}{*}{4} & Sebelum & 2 & 1 & 0 \\
\hline & Sesudah & 3 & 3 & 1 \\
\hline
\end{tabular}

Sumber: Dokumentasi Pribadi 2020

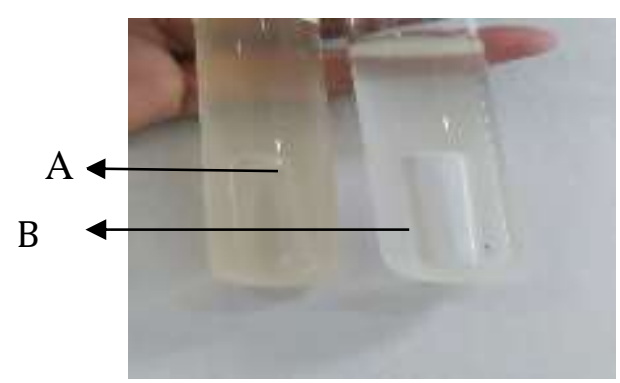

Gambar 1. Hasil uji praduga dengan media LB. Keterangan: (A) Hasil positif terdapat gelembung gas, (B) Hasil negatif tidak terdapat gelembung gas.

Berdasarkan hasil uji praduga, jumlah tabung dari semua sampel air sebelum dan sesudah digunakan untuk mencuci peralatan makan menunjukkan hasil positif yang beragam dan memiliki perbedaan pada setiap inokulum $10 \mathrm{~mL}, 0,1 \mathrm{~mL}$, dan $1 \mathrm{ml}$ (Tabel 2). Menurut Khairunnisa (2012) semakin sedikit kandungan coliform pada sampel air maka kualitas air semakin baik dan sebaliknya semakin banyak kandungan bakteri coliform maka kualitas air semakin buruk. Untuk memastikan sampel yang positif mengandung bakteri coliform atau tidak, perlu dilakukan uji lanjutan yaitu uji penegasan untuk menegaskan keberadaan bakteri coliform karena hasil positif dari uji praduga tidak selalu disebabkan oleh bakteri coliform (Alang, 2015).

\section{Uji Penegasan}

Pada uji penegasan, menggunakan media yaitu BGLB (Brillian green laktosa broth), yang digunakan untuk mendeteksi adanya bakteri coliform, komposisi dari media BGLB berupa garam empedu dan laktosa sehingga mampu membuat bakteri 
coliform tumbuh dengan optimal, selain itu juga memiliki kandungan garam ox bile berfungsi sebagai inhibitor untuk menghambat pertumbuhan bakteri gram positif sehingga bakteri yang tumbuh berupa bakteri gram negatif (Fardiaz, 1989). Hasil positif uji penegasan yaitu terbentuknya gelembung gas yang terdapat pada tabung durham (Gambar 3).

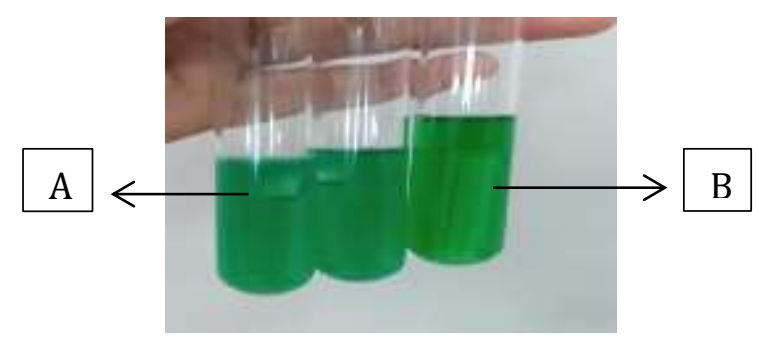

Gambar 3. Hasil uji penegas dengan media BGLB Keterangan: (A) Hasil poitif terdapat gelembung gas (B) Hasil negatif tidak terdapat gelembung gas. (Sumber: Dokumentasi Pribadi 2020)

Tabel 3. Hasil Uji Penegasan

\begin{tabular}{|c|c|c|c|c|c|c|c|}
\hline & \multirow[b]{2}{*}{ Sampel } & \multirow[b]{2}{*}{$\begin{array}{c}\text { Sumber } \\
\text { Air }\end{array}$} & \multicolumn{3}{|c|}{ Hasil Uji Penegasan } & \multirow{2}{*}{$\begin{array}{c}\text { Jumlah } \\
\text { Bakteri } \\
\text { MPN/100ml }\end{array}$} & \multirow[b]{2}{*}{ Keterangan } \\
\hline & & & $\begin{array}{c}3 \times 10 \\
\mathrm{ml}\end{array}$ & $\begin{array}{c}3 \times 1 \\
\mathrm{ml}\end{array}$ & $\begin{array}{c}3 \times 0,1 \\
\mathrm{ml}\end{array}$ & & \\
\hline \multirow{2}{*}{1} & Sebelum & Air & 2 & 2 & 1 & 26 & TMS \\
\hline & Sesudah & Sumur & 3 & 2 & 1 & 95 & TMS \\
\hline \multirow{2}{*}{2} & Sebelum & Air & 2 & 1 & 1 & 20 & TMS \\
\hline & Sesudah & PDAM & 3 & 1 & 2 & 72 & TMS \\
\hline \multirow{2}{*}{3} & Sebelum & Air & 2 & 2 & 1 & 26 & TMS \\
\hline & Sesudah & Sumur & 3 & 3 & 0 & 190 & TMS \\
\hline \multirow{2}{*}{4} & Sebelum & Air & 2 & 1 & 0 & 15 & TMS \\
\hline & Sesudah & PDAM & 3 & 3 & 1 & 271 & TMS \\
\hline
\end{tabular}

Sumber: Dokumentasi Pribadi 2020

Keterangan : TMS = Tidak memenuhi syarat kualitas air bersih dengan batas maksimum total coliform MPN yaitu $10 / 100 \mathrm{ml}$ untuk air perpipaan, dan $50 / 100 \mathrm{ml}$ untuk air non perpipaan.

MS = Menenuhi syarat kualitas air bersih dengan batas maksimum total coliform MPN yaitu 10/100 ml untuk air perpipaan, dan 50/100 ml untuk air non perpipaan.

Berdasarkan hasil uji MPN, diketahui semua sampel yaitu air sebelum dan sesudah digunakan mencuci peralatan makan PKL tidak memenuhi syarat. Pada sampel air sebelum digunakan, sampel air 1 dan 3 memiliki jumlah coliform yang sama yaitu 26/100 $\mathrm{mL}$, dan pada sampel 2 memiliki nilai $20 / 100 \mathrm{ml}$, sedangkan pada sampel 4 memiliki nilai yaitu $15 / 100 \mathrm{~mL}$, pada air sebelum digunakan tidak 
memenuhi syarat sesuai dengan Peraturan Menteri Kesehatan Republik Indonesia No. 416 Tahun 1990 tentang syarat kualitas air bersih dengan batas maksimum total coliform (MPN) yaitu 10/100 ml untuk air perpipaan dan 50/100 ml untuk air non perpipaan. Pada air setelah digunakan mencuci peralatan makan juga tidak memenuhi syarat, hal ini dikarenakan PKL tidak memperhatikan air yang digunakan mencuci peralatan makan, pedagang juga mengambil air yang diambil dari sumbernya kemudian dimasukkan kedalam ember yang belum dibersihkan sehingga air terkontaminasi mikroba. Menurut Permenkes (1990) bahwa kualitas air yang digunakan untuk memenuhi kebutuhan sehari-hari haruslah memenuhi persyaratan fisik, kimia, serta biologis, dan air tidak boleh tercemar oleh mikroba.

Pada air sesudah digunakan mencuci peralatan makan PKL memiliki jumlah bakteri coliform yang meningkat dibandingkan dengan air sebelum digunakan mencuci peralatan makan, dengan jumlah cemaran mikroba dan coliform yaitu pada sampel 1 memiliki nilai 95/100 mL, pada sampel 2 memiliki nilai 72/100 $\mathrm{mL}$, pada sampel 3 memiliki nilai 190/100 mL, dan sampel 4 memiliki nilai tertinggi yaitu 271/100 mL, hal ini dapat disebabkan karena lingkungan disekitar tempat PKL berjualan kumuh dan kebersihan kurang diperhatikan sehingga menjadi penyebab tingginya nilai
MPN. Selain itu, air yang digunakan mencuci peralatan makan tidak mengalir, dan digunakan secara berulang-ulang sehingga menyebabkan sisa kotoran mencemari air (Henry, dkk. 2013). Kontaminasi pada air sesudah digunakan mencuci peralatan makan juga disebabkan oleh praktek higiene sanitasi PKL yang kurang tepat pada proses pencucian peralatan makan, dengan menggunakan bak pencucian dan tidak mengganti air bilasan yang sudah kotor (Rara, dkk. 2017). Dari hasil observasi PKL mencuci peralatan makan menggunakan ember dengan kondisi air yang tidak mengalir, sehingga memungkinkan air terkontaminasi oleh mikroba. Penelitian yang dilakukan oleh Budon (2013) tentang kualitas air pencucian peralatan makan dikantin UIN Alauddin Makassar, bahwa dari 4 sampel, 3 sampel tidak memenuhi syarat, dan hanya 1 sampel yang memenuhi syarat sesuai dengan Permenkes Tahun 1990.

Sedangkan penelitian yang dilakukan Kusuma (2015) air kobokan dirumah makan Kelurahan Andalas Kecamatan Padang Timur, hampir semua sampel memiliki nilai MPN yang sama yaitu $>2400 / 100 \mathrm{ml}$ kecuali pada sampel ke 8 dan dapat dikatakan bahwa air tidak memenuhi syarat mikrobiologis sesuai dengan Permenkes No.416 Tahun 1990. 


\section{Uji Pelengkap}

Hasil positif dari uji penegasan dilanjutkan ke uji pelengkap (Complete Test) untuk mengetahui terdapatnya bakteri Escherichia coli atau bakteri coliform lainnya dengan menginokulasikan sampel yang positif pada media BGLB untuk digoreskan ke media EMBA. Media EMBA merupakan media selektif dan diferensial yang digunakan untuk mendeteksi keberadaan bakteri coliform (Dad, 2000). Hasil positif dari bakteri Escherichia coli pada permukaan media EMBA ditumbuhi koloni berwarna hijau metalik dengan disertai kilap logam (Gambar 3.) (Jorgensen, 2015).

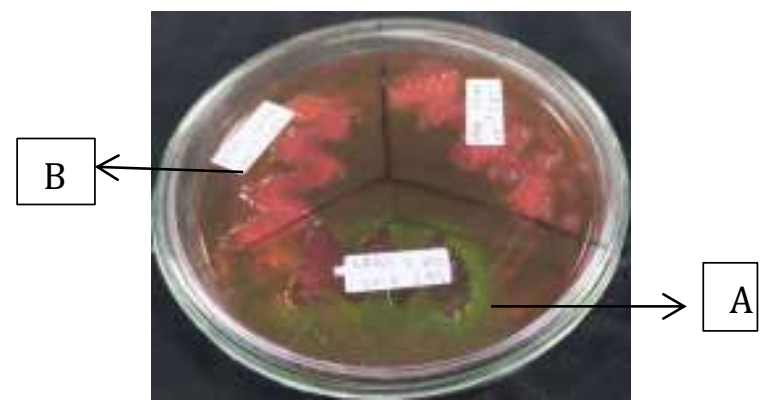

Gambar 3. Hasil uji pelengkap menggunakan media EMB Keterangan: (A) Hasil positif Escherichia coli bewarna hijau metalik, (B) Hasil negatif Escherichia coli tidak bewarna hijau metalik. (Sumber: Dokumentasi Pribadi 2020)

Berdasarkan hasil penelitian, sampel

1, dan 3 air sebelum dan sesudah digunakan mencuci peralatan makan PKL memiliki koloni berwarna hijau mengkilap. Menurut Brooks et al. (2010) warna hijau metalik pada permukaan media EMBA menandakan tumbuhnya bakteri Escherichia coli yang memfermentasi laktosa sehingga meningkatkan kadar asam yang mampu mengendapkan methilen blue sehingga menimbulkan warna hijau metalik.

Pada sampel 2 dan 4 air sebelum digunakan mencuci peralatan makan PKL pada inokulum $10 \mathrm{ml}, 1 \mathrm{ml}$, dan $0,1 \mathrm{ml}$ memiliki koloni berwarna merah muda tetapi pada sampel 2 inokulum $1 \mathrm{ml}$ air sebelum digunakan mencuci peralatan makan koloni berwarna merah muda, dan pada air sesudah digunakan mencuci peralatan makan koloni berwarna hijau metalik. Pada sampel air sebelum digunakan mencuci peralatan makan PKL memiliki koloni berwarna merah muda hal ini karena air terkontaminasi genus Enterobacter tetapi pada air sesudah digunakan koloni berwarna hijau metalik karena air sudah digunakan untuk mencuci peralatan makan sehingga menjadikan air terkontaminasi oleh bakteri Escherichia coli. Menurut Holt (1994) genus Enterobacter memiliki koloni berwarna merah muda.

Berdasarkan penelitian Zulfa (2011) bahwa salah satu faktor penting dalam higiene adalah menggunakan air bersih dan mengalir. Selain itu, pencucian peralatan makan juga harus diperhatikan, karena meskipun air dalam kondisi bersih tetapi digunakan secara berulang-ulang, akan menjadikan air terkontaminasi bakteri Escherichia coli.

Bakteri Escherichia coli dapat menyebar melalui air dan akan mengkontaminasi bahan yang bersentuhan 
dengan air tersebut, sehingga dalam proses pengolaan makanan dan nantinya tetelan manusia akan menyebabkan penyakit seperti diare (Faridz, 2007). Sedangkan menurut Andrian (2014) adanya bakteri Escherichia coli yang terdapat pada air perlu diwaspadai karena bakteri ini dapat menyebabkan penyakit seperti diare, demam tifoid dan lain-lain. Selain itu, bakteri Eterobacter sp. banyak ditemukan di air, bakteri patogen ini biasa menyerang usus dan menyebabkan infeksi oportunistik di saluran pencernaan.

\section{Pengujian Bakteri Salmonella sp.}

Untuk mengetahui terdapat atau tidaknya bakteri Salmonella, maka dilakukan pengujian menggunakan media SSA (Salmonella Shigella Agar) (Gambar 4). Media SSA merupakan media selektif (kompleks) (Ningrum, 2014). Bakteri Salmonella ditandai dengan ciri mikroskopi berbentuk bulat dan permukaan rata, memiliki warna cerah transparan, berwarna merah muda dan memiliki warna bening sampai buram, memiliki inti hitam pada bagian tengah serta memproduksi $\mathrm{H}_{2} \mathrm{~S}$ (Engelkirk \& Duben, 2008).

Berdasarkan hasil pengujian menggunakan media SSA untuk mengetahui terdapat atau tidaknya bakteri Salmonella pada sampel air yang digunakan mencuci peralatan makan PKL yang berada di sekitar Universitas Islam Negeri Sunan Ampel Surabaya didapatkan hasil bahwa seluruh sampel yaitu sampel ke-1, 2, 3, dan 4 memiliki ciri berbentuk bulat, berwarna merah muda dengan pinggiran rata dan berwarna kuning pada bagian dasar, ciri-ciri tersebut diduga adalah bakteri Salmonella. Hal ini sesuai dengan penelitian Wahyuni (2018) bahwa bakteri Salmonella memiliki bentuk koloni bulat, halus, kuning tidak berwarna (bening) dan ada atau tidaknya inti berwarna hitam, perubahan warna hitam karena mampu menghasilkan $\mathrm{H}_{2} \mathrm{~S}$.

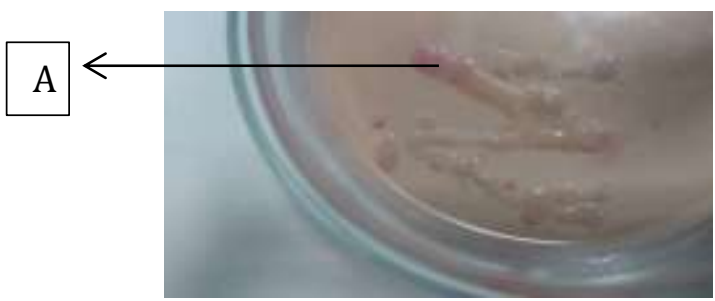

Gambar 4. Hasil Uji Salmonella menggunakan media SSA Keterangan: (A) Hasil SSA berwarna merah muda (Sumber: Dokumentasi Pribadi 2020)

$$
\text { Untuk memperkuat hasil uji }
$$
Salmonella dilanjutkan ke uji biokimia TSIA (Triple Sugar Iron Agar) dengan melihat kemampuan bakteri dalam memfermentasi karbohidrat, serta menghasilkan $\mathrm{H}_{2} \mathrm{~S}$, asam dan gas. Media TSIA terdiri dari sukrosa, glukosa, laktosa, dan fero sulfat serta sodium tiosulfat untuk mendeteksi adanya gas $\mathrm{H}_{2} \mathrm{~S}$ (Putri, 2016).

Hasil positif dari uji TSIA ditandai dengan perubahan warna pada media yaitu kuning pada butt (dasar) dan merah pada slant (permukaan miring), dan memproduksi $\mathrm{H}_{2} \mathrm{~S}$ sehingga berwarna hitam (Gambar 5). perubaan warna yang terjadi pada media 
bagian dasar berwarna kuning, karena mikroorganisme hanya mefermentasi glukosa, dan warna hitam pada lereng media disebabkan oleh adanya $\mathrm{H}_{2} \mathrm{~S}$ karena terjadi pengendapan fero sulfida (Cappuccino \& Sherman, 2014).

Berdasarkan hasil penelitian uji biokimia TSIA, didapatkan hasil bahwa pada sampel ke-1 dan ke-2 pada bagian bawah berwarna kuning dan bagian miring berwarna merah, pada sampel ke-3 dan ke-4 berwarna hitam pada bagian bawah dan kuning pada bagian miring media.

Dari hasil tersebut semua sampel dikatakan positif Salmonella karena mampu memfermentasi glukosa dan memproduksi $\mathrm{H}_{2} \mathrm{~S}$, pada bagian miring (Slant) permukaan dan berubah warna menjadi merah yang menunjukkan sifat alkalis (K), pada tusukan media berwarna kuning menunjukkan senyawa glukosa yang bersifat asam (A), dan memproduksi $\mathrm{H}_{2} \mathrm{~S}$ yang bewarna hitam, menghasilkan gas pada bagian tengah media membentuk gelembung seperti rongga kosong (Holt, 1994).

Menurut penelitian Marissa (2014) air yang digunakan mencuci peralatan makan menggunakan air PDAM, dikatakan positif Salmonella sp. hal ini dikarenakan pencucian peralatan makan dengan menggunakan air yang tidak mengalir. Sedangkan menurut Andriansyah (2008) pencucian peralatan makan di warung Jember tidak menggunakan air yang mengalir menjadikan air positif terkontaminasi oleh bakteri Salmonella.

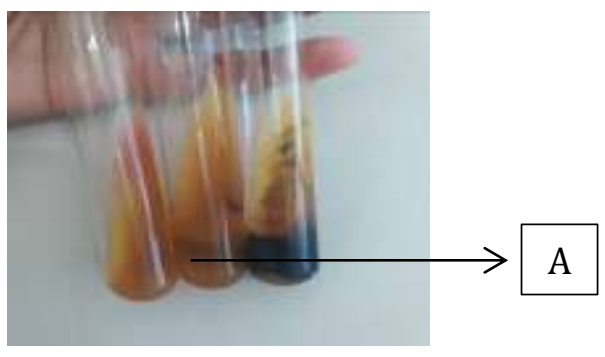

Gambar 5. Hasil Uji TSIA Keterangan: (A) Bagian dasar bewarna kuning, dan bagian miring merah (Sumber: Dokumentasi Pribadi 2020

\section{KESIMPULAN}

Berdasarkan Berdasarkan hasil uji TPC dari 8 sampel, 4 sampel air sebelum digunakan mencuci peralatan makan ole PKL memiliki jumlah koloni terendah yaitu 3,0 x $10^{2} \mathrm{Cfu} / \mathrm{ml}$ dan tertinggi yaitu 9,8 $\times 10^{5}$ $\mathrm{Cfu} / \mathrm{ml}$, sedangkan pada 4 sampel sesudah digunakan mencuci peralatan makan PKL memiliki jumlah koloni terendah yaitu 4,0 x $10^{2} \mathrm{Cfu} / \mathrm{ml}$ dan tertinggi yaitu $3,5 \times 10^{5}$ $\mathrm{Cfu} / \mathrm{ml}$. Pada hasil uji MPN air sebelum digunakan dengan jumlah terendah yaitu 15/100 ml dan tertinggi 26/100 ml, dan air sesudah dengan jumlah terendah yaitu $72 / 100 \mathrm{ml}$ dan tertinggi $271 / 100 \mathrm{ml}$ sehingga tidak memenuhi syarat sesuai Permenkes No 416 Tahun 1990 tentang syarat kualitas air bersih dengan batas maksimum total coliform (MPN) yaitu 10/100 ml untuk air perpipaan dan 50/100 ml untuk air non perpipaan. Escherichia coli terdeteksi pada semua sampel 1 \& 3 , sedangkan pada sampel 2 Escherichia coli 
terdeteksi pada air sesudah sedangkan pada air sebelum terdeteksi genus Enterobacter dan pada semua sampel 4 terdeteksi genus Enterobacter dan semua sampel air yang digunakan mencuci peralatan makan PKL dinyatakan positif Salmonella.

\section{DAFTAR PUSTAKA}

Agus, Prayitno. 2009. Uji Bakteriologi Air dan Air Siap Konsumsi dari PDAM Surakarta Ditinjau dari Jumlah Bakteri Choliform. Skripsi. Fakultas Keguruan dan Ilmu Pendidikan Universitas Muhamadiyah, Surakarta.

Alang, Hasria. 2014. Analisis Coliform Kualitas Air Galon Berdasarkan Lama Penyimpanannya di Kecamatan Rappocini Kota Makasar. Jurnal Biotek, Vol 1(1): 43-50.

Andrian, G.B., Fatimawali, \& Novel, S. Kojong. 2014. Analisis Cemaran Bakteri Coliform dan Identifikasi Escherichia coli Pada Air Isi Ulang dari Depot Di Kota Manado. Jurnal Ilmiah Farmasi Pharmacon, Vol 3(3).

Andriansyah, H. 2008. Kontaminasi Air Cucian Alat Makan Yang Tidak Mengalir Oleh Salmonella Di Warung Makan Wilayah Kampus Universitas Jember.Skripsi. Fakultas Kedokteran Universitas Jember.

Brooks, G.F., Carroll, K.C., Butel, J.S., Morse, S.A. dan Mietzner.T.A. 2010. Mikrobiologi Kedokteran Jwets, Melning \& Adelberg's. Penerbit buku kedokteran. EGC Jakarta.

Budiati, R.E. 2015. Pemeriksaan Koloni Bakteri Air Bak Cuci di Warung Makan Pasar X Kabupaten Kudus Tahun 2015. Jurnal Kesehatan Masyarakat. Stikes Cendekia Utama
Kudus.

Budon, A.S. 2013. Studi Bakteriologis Air Pencucian dan Peralatan Makan Dikantin UIN Alauddin Makassar. Skripsi. Fakultas Ilmu Kesehatan Universitas Islam Negeri Alauddin, Makassar.

Cappuccino, J.G \& Sherman, N. 1987. Microbiology : A Laboratory Manual. The Benjamin/Cummings Publishing Company, Inc. Menlo Park, California.

Dad. 2000. Bacterial Chemistry and Physicology. John Wiley \& Sons, Ins, New York, P.426.

Depkes Ri. 2011. Pedoman Hygiene Sanitasi Depot Air Minum. Dirjen P2PL Jakarta.

Engelkirk, P.G., Burton, G.R.W. 2008. Burton's Microbiology For The Health Sciences $8^{\text {th }}$ Edition. Philadelphia.

Fardiaz. 1989. Analisis mikrobiologi pangan. Departemen pendidikan dan kebudayaan IPB, Bogor.

Faridz.2007. Analisis Jumlah Bakteri Dan Keberadaan Escherichia Coli Pada Pengolahan Ikan Teri Nasi Di PT Kelola Mina Laut Sumenep. Jurnal Embryo, 2 (4):94-106.

Harmayani, K.D dan Konsukartha, I.G.M. 2007. Pencemaran Air Tanah Akibat Pembuangan Limbah Domestik Dilingkungan Kumuh. Jurnal Pemukiman Tanah, Vol 5. No.2 Hal:62-108.

Henry, Jilfer, Sinolungan. 2013. Hubungan Antara Perilaku Penjamah Makanan Dengan Angka Kuman Pada Peralatan Makan Di Warung Makan Kawasan Pantai Malalayang Kota Manado. Jurusan Kesehatan Masyarakat Universitas Negeri Gorontalo.

Holt, JG, NR, Krieg, PHA, Sneath, JT, Staley \& 
ST, Williams. 1994. 'Bergey's Menual of Determinative Bacteriology, 9 th Edition, A Wolters Kluwer Company, Philadelphia.

Jorgensen. J.H \& Ferraro, M.J. 2009. Antimicrobial susceptibility testing: a review of general principles and contemporary practices, medical microbiology, 49: ISSN 1750.

Khairunnisa. 2012. Pengaruh Jarak dan Kontruksi Sumur Serta Tindakan Penggunaan Air Terhadap Coliform Air Sumur Gali Penduduk Di Sekitar Pasar Hewan Desa Cempeudak Kecamatan Tanah Jambo Aye Kabupaten Aceh Utara. Tesis. Fakultas Kesehatan Masyarakat Universitas Sumatera Utara, Medan.

Kusuma, A.E., Rasyid, R., dan Endrinaldi. 2015. Identifikasi Bakteri coliform Pada Air Kobokan Di Rumah Makan Kelurahan Abdalas Kecamatan Padang Timur. Jurnal Kesehatan Andalas.

Marrisa, N., Dan Arifin, A.Y. 2014. Higienitas Peralatan Makan Berdasarkan Keberadaan Salmonella

Sp. diwarung Makan Kota Banda Aceh. Jurnal Penelitian Kesehatan. Departemen Kesehatan Republik Indonesia Badan Penelitian Dan Pengembangan.

Melawati. 2010. Survey Kontaminasi Bakteri Patogen Pada Makanan Dan Minuman Yang Dijual Disekitar Gedung Perkantoran Dijakarta, Jakarta.

Nicolas, B.,Abdoul, R., Brllo., Aly, S.,Amadou, T., Cheik, O., A. Jules Ilbuodo. 2006. Hygienic Status Assessment of Dish Washing Waters, Utensils, Hands And Pieces Of Money From Street Food Processing Sites In Ougsdougou (Burkina Faso). Africa: University Ouagadougou. Burkina Faso, Vol 5 Hal 1107-1112.
Ningrum. 2014. Annalisis Kandungan Salmonella Sp Dan Kandungan Formalinang Terdapat Pada Makanan Otak-Otak Bandeng (Chanos chanos forsk) Yang Dijual Di Toko Oleh-Oleh Kota Gresik Sebagai Sumber Belajar Biologi SMA. Skripsi. Universitas Muhamadiyah Malang, Malang.

Nugroho, A. 2006. Bioindikator Kualitas Air. Cetakan 1. Universitas Trisakti, Jakarta.

Paulus, Hariyono. 2007. Sosiologi Kota Untuk Arsitek. Bumi Aksara, Jakarta.

Peraturan Menteri Kesehatan Nomor. 416 Tahun 1990. Tentang Syarat-Syarat dan Pengawasan Kualitas Air. Menteri Kesehatan Republik Indonesia.

Pleczart, M.J. And E.C.S. 2008. Dasar-Dasar Mikrobiologi. Universitas Indonesia Press, Jakarta.

Prasumma,A. 2013. Pemeriksaan Bakteri Coliform Dalam Air Cucian Alat Makan Pada Warung-Warung Dipabelan Sukohardjo. Naskah Publikasi. Fakultas Kedokteran UniversitasMuhamadiyah,Surakarta.

Putri, A.M., dan Kurnia, P. 2018. Identifikasi Keberadaan Bakteri Coliform dan Total Mikroba Dalam Es Dung-Dung Di Sekitar Kampus Universitas Muhammadiyah Surakarta. Media Gizi Indonesia, 13(1): 41-45.

Suryanti, A., Amir,R., dan Makhrajani Majid. 2019. Pemeriksaan Escherichia coli Menggunakan Metode Usap Pada Peralatan Makan Dirumah Sakit Umum Andi Makkasau Kota Parepare. Program Studi Kesehatan Masyarakat Fakultas Ilmu Kesehatan Universitas Muhammadiyah, 2(1).

Rara, Putri, \& Hesty. 2017. Teknik Pencucian Alat Makan, Personal Hygiene 
Terhadap Kontaminasi Bakteri Pada Alat Makan. Program Studi Kesehatan Masyarakat

Stikes Harapan Ibu Jambi.

Wahyuni, R.M., Sayuti, A., Abrar, M., Erlina, Hasan, M., Dan Zainuddin. 2018. Isolasi dan Identifikasi Bakteri Enteric Patogen Pada Badak Sumatera (Dicerorhinus Sumatranensis) Di Suaka Rhino Sumatera (SRS) Taman Nasional Way Kambas (TNWK), JIMVET E-ISSN: 2540-9492. Lampung.

Zulfa, N. 2011. Hubungan Hygiene Personal Pedagang dan Sanitasi Makanan Dengan Keberadaan Escherichia coli Pada Nasi Rames di Pasar Johar. Skripsi. Universitas Negeri Semarang, Semarang. 